3-1-2015

\title{
Fossils of Putative Marine Algae from the Cryogenian Glacial Interlude of Mongolia
}

Phoebe A. Cohen

Williams College

Francis A. Macdonald

Harvard University

Sara Pruss

Smith College,spruss@smith.edu

Emily Matys

Massachusetts Institute of Technology

Tanja Bosak

Massachusetts Institute of Technology

Follow this and additional works at: https://scholarworks.smith.edu/geo_facpubs

Part of the Geology Commons

\section{Recommended Citation}

Cohen, Phoebe A.; Macdonald, Francis A.; Pruss, Sara; Matys, Emily; and Bosak, Tanja, "Fossils of Putative Marine Algae from the Cryogenian Glacial Interlude of Mongolia" (2015). Geosciences: Faculty

Publications, Smith College, Northampton, MA.

https://scholarworks.smith.edu/geo_facpubs/123

This Article has been accepted for inclusion in Geosciences: Faculty Publications by an authorized administrator of Smith ScholarWorks. For more information, please contact scholarworks@smith.edu 


\title{
FOSSILS OF PUTATIVE MARINE ALGAE FROM THE CRYOGENIAN GLACIAL INTERLUDE OF MONGOLIA
}

\author{
Authors: COHEN, PHOEBE A., MACDONALD, FRANCIS A., PRUSS, \\ SARA, MATYS, EMILY, and BOSAK, TANJA
}

Source: Palaios, 30(3) : 238-247

Published By: Society for Sedimentary Geology

URL: https://doi.org/10.2110/palo.2014.069

BioOne Complete (complete.BioOne.org) is a full-text database of 200 subscribed and open-access titles in the biological, ecological, and environmental sciences published by nonprofit societies, associations, museums, institutions, and presses.

Your use of this PDF, the BioOne Complete website, and all posted and associated content indicates your acceptance of BioOne's Terms of Use, available at www.bioone.org/terms-of-use.

Usage of BioOne Complete content is strictly limited to personal, educational, and non - commercial use. Commercial inquiries or rights and permissions requests should be directed to the individual publisher as copyright holder.

BioOne sees sustainable scholarly publishing as an inherently collaborative enterprise connecting authors, nonprofit publishers, academic institutions, research libraries, and research funders in the common goal of maximizing access to critical research. 


\title{
FOSSILS OF PUTATIVE MARINE ALGAE FROM THE CRYOGENIAN GLACIAL INTERLUDE OF MONGOLIA
}

\author{
PHOEBE A. COHEN, ${ }^{1}$ FRANCIS A. MACDONALD, ${ }^{2}$ SARA PRUSS, ${ }^{3}$ EMILY MATYS,${ }^{4}$ aNd TANJA BOSAK ${ }^{4}$ \\ ${ }^{1}$ Department of Geosciences, Williams College, 947 Main Street, Williamstown Massachusetts 01267 USA \\ ${ }^{2}$ Department of Earth and Planetary Sciences, Harvard University, Cambridge, Massachusetts 02138 USA \\ ${ }^{3}$ Department of Geosciences, Smith College, Northampton, Massachusetts 01063 USA \\ ${ }^{4}$ Department of Earth, Atmospheric and Planetary Sciences, Massachusetts Institute of Technology, Cambridge, Massachusetts 02139 USA \\ e-mail: Phoebe.A.Cohen@williams.edu
}

\begin{abstract}
Neoproterozoic carbonate successions provide a new taphonomic window into the diversification of eukaryotes. We report recently discovered macroscopic organic warty sheets (MOWS) in macerates of limestone from the ca. 662-635 Ma Taishir Formation (Tsagaan Olom Group, Mongolia). Sheets are applanate. One surface contains raised ridges and conspicuous, $\sim 100-\mu \mathrm{m}$-tall warty protuberances with depressed tops that enclose internal cavities containing cellular structures. The Taishir MOWS may be the remains of unusual bacterial, protistan, or fungal biofilms, or a previously undocumented, extinct taxon. However, multiple lines of evidence including the morphology of warty protuberances and the presence of cellular architecture within protuberances support the interpretation of MOWS as marine algae, perhaps a member of the Rhodophyta. Regardless of their specific taxonomic affiliation, MOWS increase the diversity of biota reported from the Cryogenian glacial interlude and indicate the presence of macroscopic and morphologically complex multicellular organisms in the Cryogenian.
\end{abstract}

\section{INTRODUCTION}

Assemblages of microscopic prokaryotic and eukaryotic organisms dominate the Neoproterozoic fossil record before the late Ediacaran (e.g., Vidal and Ford 1985; Knoll et al. 2006). Although fossil diversity increases through the Neoproterozoic Era, the Cryogenian nonglacial interlude between the Sturtian and Marinoan Snowball Earth events has been generally viewed as depauperate (Knoll et al. 2006) and devoid of both microscopic and macroscopic fossils. Rare exceptions to this may be the macroscopic fossils of putative sponges from Australia (Maloof et al. 2010) and enigmatic disk-shaped impressions from Canada (Hofmann et al. 1990). Recent work, however, has shown that carbonates from the Cryogenian nonglacial interlude host a diversity of eukaryotic fossils, including agglutinated fossils similar to modern foraminifera and lobose testate amoebae as well as organic-walled tests similar to some modern ciliates (Bosak et al. 2011a, 2011b, 2011c; Dalton et al. 2013). These assemblages differ from earlier and later Neoproterozoic assemblages documented in shale and chert units. Here, we add macroscopic organic warty sheets (MOWS), tentatively interpreted as marine algae, to this record of carbonate-hosted fossils. MOWS expand the diversity of eukaryotic fossils between the Sturtian and the Marinoan low-latitude glaciation events and improve the record of ecological, biogeochemical, and environmental transitions during the Cryogenian.

\section{GEOLOGICAL SETTING}

Fossils were recovered from the Cryogenian Taishir Formation of the Tsagaan Olom Group on the Zavkhan Terrane of Mongolia (Fig. 1; Macdonald et al. 2009; Macdonald 2011). The cap carbonate at the base of the Taishir Formation has been correlated globally with Sturtian cap carbonates using $\mathrm{C}$ and $\mathrm{Sr}$ isotope chemostratigraphy (Macdonald et al. 2009), which has been dated at $662 \pm 4 \mathrm{Ma}$ in northwestern Canada (Rooney et al. 2014) and $663 \pm 4$ Ma in South China (Zhou et al. 2004). The Khongoryn diamictite at the top of the Taishir Formation contains intricately striated clasts (pictured in online field photo repository of Macdonald et al. 2011) and has been correlated with Marinoan-aged glacial deposits (Macdonald et al. 2009; Shields-Zhou et al. 2012; Johnston et al. 2013), which have been dated globally at ca. $636 \mathrm{Ma}$ (Calver et al. 2013), thus constraining the age of the fossil material to between ca. 662 and $635 \mathrm{Ma}$. We here follow Bold et al. (2013) and use the Mongolian spelling for the recently formalized stratigraphy.

The Taishir Formation consists of $\sim 350-550 \mathrm{~m}$ of dark-gray carbonate grainstone and wackestone facies deposited on a carbonate ramp (Macdonald et al. 2009; Bold et al. 2013). The succession consists of large-scale shallowing-upward sequences, which contain smaller-order parasequences (Bold et al. 2013). Complete 1-5-meter-scale peritidal parasequences begin with transgressive lag deposits of packstone or wackestone, succeeded upward by thin-bedded micrite, ribbon-bedded calcisiltite, and massive to cross-bedded grainstone, and are capped with exposure surfaces. All MOWS were discovered in wackestone facies of the transgressive lag deposits at the base of parasequences at three stratigraphic horizons in samples collected from outcrop at the Khongoryn section, (F704 at N 46 $41.97^{\prime}$, E $96^{\circ} 14.92^{\prime}$ ), and two sections

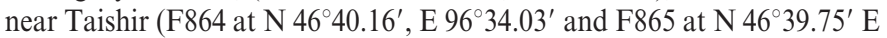
$96^{\circ} 34.33^{\prime}$; Fig. 1). Carbon isotope data and putative ciliate fossils were previously reported from these sections by Bosak et al. (2011b), and are replotted in Figure 1B.

\section{MATERIALS AND METHODS}

Carbonate hand samples from sections F704, F864, and F865 were washed with deionized water and dissolved in 10\%-20\% acetic acid or $10 \%$ hydrochloric acid for $24-48$ hours to clean the surface. The samples 


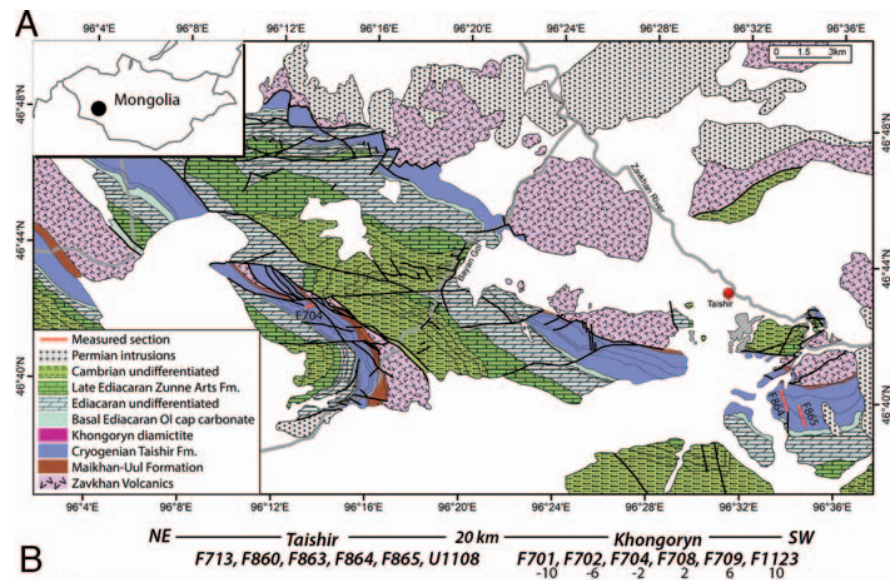

B

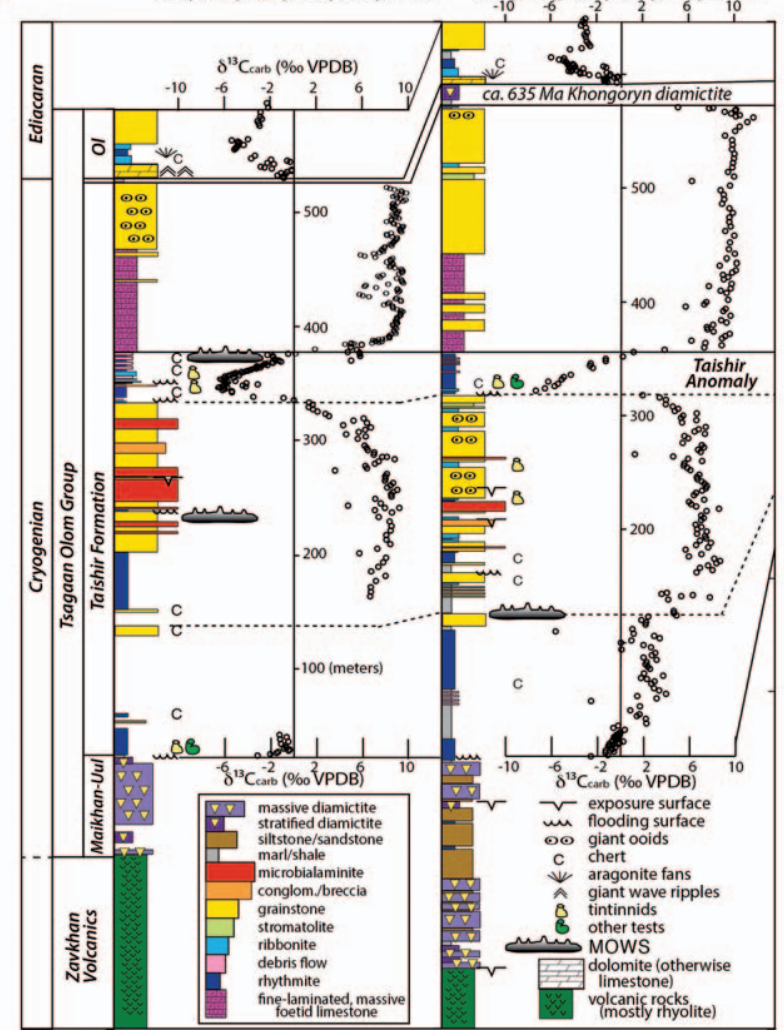

FIG. 1.-A) Map showing location of fossiliferous sections F864, F865, and T704; black circle in inset map of Mongolia shows approximate location shown in geological map. B) Stratigraphic sections of fossiliferous localities, adapted from Bosak et al. (2011b). Each column is a composite of multiple measured sections noted at top; Taishir (left column) refers to sections F864 and F865 noted in A, Khongoryn (right column) refers to section F704 noted in A.

were then washed with nanopure water and broken into approximately 0.5 -cm-diameter pieces and dissolved in $10 \% \mathrm{HCl}$. Residues were rinsed with nanopure water and examined with light microscopy, scanning electron microscopy (SEM), and Raman spectroscopy. Raman spectra of select macerated material were collected nondestructively at room temperature with a WITec confocal Raman microscope and WITec Control software at the Center for Nanoscale Systems (CNS) at Harvard University. Points of interest were identified by a transmitted light microscope connected to the spectrometer. Point targets were excited using a 532-nm-wavelength laser of $50 \mathrm{~mW}$ output power. Raman spectra were obtained in the interval of $0-2,500 \mathrm{~cm}^{-1}$ and analyzed with WITec Project software.
Some pieces of macerated material were air dried and embedded in Epon epoxy for 24 hours, then cut into $1 \mu \mathrm{m}$ slices with a glass knife and examined by transmitted light microscopy. These samples were uncoated and coverslips were not placed on slides, thus immersion oil used during the process of imaging was in direct contact with the sample. Other pieces of macerated material were cut with a small metal knife under a lowmagnification microscope to better reveal internal structures and textures. For SEM analyses, macerated samples were air dried and coated with either $\mathrm{Au}$ or $\mathrm{Pt} / \mathrm{Pd}$ and examined with an FEI scanning electron microscope with attached energy-dispersive X-ray spectroscopy analyzer. Thin sections of carbonate hand samples $(30 \mu \mathrm{m}$ thick) were examined with a Zeiss transmitting light microscope equipped with a digital camera. All described specimens are curated at the Williams College Geosciences collections.

\section{MORPHOLOGY AND COMPOSITION OF FOSSIL MATERIAL}

\section{Macerated Material}

MOWS material is readily seen in residues of macerated carbonate host rock (Fig. 2). Fossil pieces are horizontally flattened (applanate), 0.9 to $5.4 \mathrm{~mm}$ in maximum length, with surface areas ranging from $0.2 \mathrm{~mm}^{2}$ to $16.0 \mathrm{~mm}^{2}$, and thicknesses ranging from 50.8 to $342.0 \mu \mathrm{m}$ (Fig. 3A, Table 1). Original margins cannot be distinguished from those that may have been formed as the material was broken during transport and deposition or during maceration. Material is flexible when wet, while airdried pieces are more brittle and break under applied pressure. In water, the color of the MOWS material varies from dark brown to amber, and dries to a pale gray color.

All fossil material in macerates exhibits warty protuberances, ridges, and polygonal structures on one surface, which the further text will refer to as the warty surface, or W surface (Figs. 2A-B, 4A). In contrast, the opposite surface is generally featureless and smooth, and we will refer to it as the smooth or S surface (Fig. 4B). Protuberances on W surfaces are conical-tosubround structures that make a positive topographic expression (Fig. 5AC, E, I). These warty structures have circular basal cross-sections, 61$250 \mu \mathrm{m}$ in diameter (Table 1), and rise 166-232 $\mu \mathrm{m}$ from the surface of the sheet (Table 1). Protuberances have darkened circular central areas 17$80 \mu \mathrm{m}$ in diameter (Table 1, Fig. 3B) that lack surface polygons and are depressed $\sim 1 \mu \mathrm{m}$ from the perimeter of the wart top (Fig. 5I). Polygonal structures on the steep sides abruptly and cleanly transition into the depressed, smoother top surface (Fig. 5I). Cutting four protuberances through the middle revealed the interior structure of protuberances. All of the cut protuberances exhibit ovoid internal cavities $\sim 50 \mu \mathrm{m}$ in diameter directly beneath the smooth, circular, depressed central areas of the wart tops (Figs. 5H, 6). In the embedded and sectioned samples, internal cavities show distinct cellular structures (Fig. 6). These samples also show that some wart tops are characterized by a central aperture, whereas darkened organic matter covers others (Fig. 6). In one sample, an approximately 10$\mu \mathrm{m}$-tall organic-walled ring rises from the $\mathrm{W}$ surface of the fossil material; the ring has the same approximate diameter as the base of the warty structures, suggesting that it may be the remnant of a detached or degraded warty protuberance (Fig. 5J).

All specimens display ridges of organic material that run across the $\mathrm{W}$ surface, skirt warty structures, and never contain warty structures on their surfaces (Figs. 2, 4A, 5A-B, D). The $\sim 10-\mu \mathrm{m}$-wide ridges rise 30 $70 \mu \mathrm{m}$ from the surface of the plate and occasionally intersect or split to form flaplike structures. Most features on $\mathrm{W}$ surfaces in macerates exhibit small, irregular polygonal structures defined by walls composed of organic material (Fig. 5F). Polygons range in width and length from 7 $25 \mu \mathrm{m}$ and are present on all areas of $\mathrm{W}$ surfaces except for the tops of the warty protuberances. Polygonal patterns are also visible on some areas of macerated material cut with a metal knife and within some areas of embedded and sectioned material (Fig. 6A-B) 

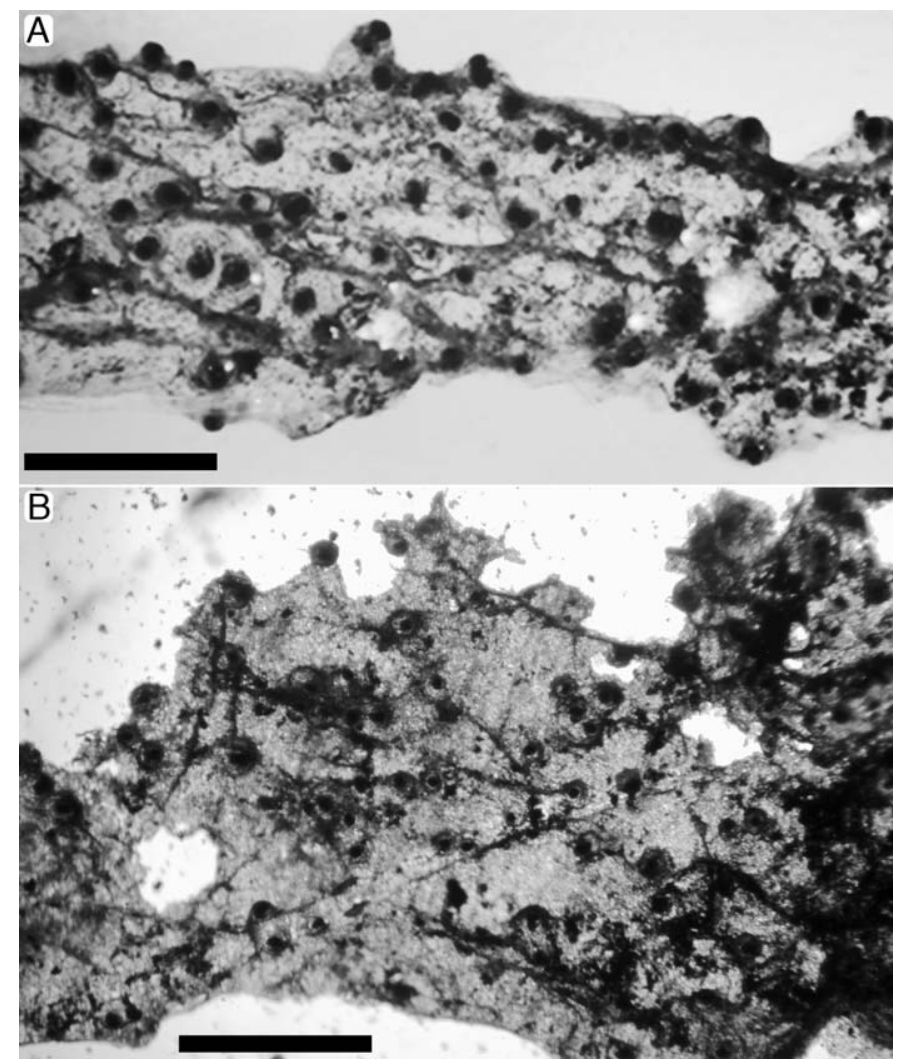

FIG. 2.-Light photomicrographs of macerated material. A) Detail of specimen F864-20-A, showing warty structures with darker central areas and ridges; scale bar is $1 \mathrm{~mm}$. B) Specimen F864-20-B showing warty structures with darker central areas and ridges; scale bar is $1 \mathrm{~mm}$.

In contrast to the $\mathrm{W}$ surfaces, which abound with warty structures, ridges, and polygonal textures, $\mathrm{S}$ surfaces are smooth and generally featureless (Fig. 4B). Small perforations often occur in S surfaces, but these do not correspond to wartlike protuberances, ridges, or flaps on the S surface (e.g., Fig. 4A-B).

A Maximum Dimension of fossil material

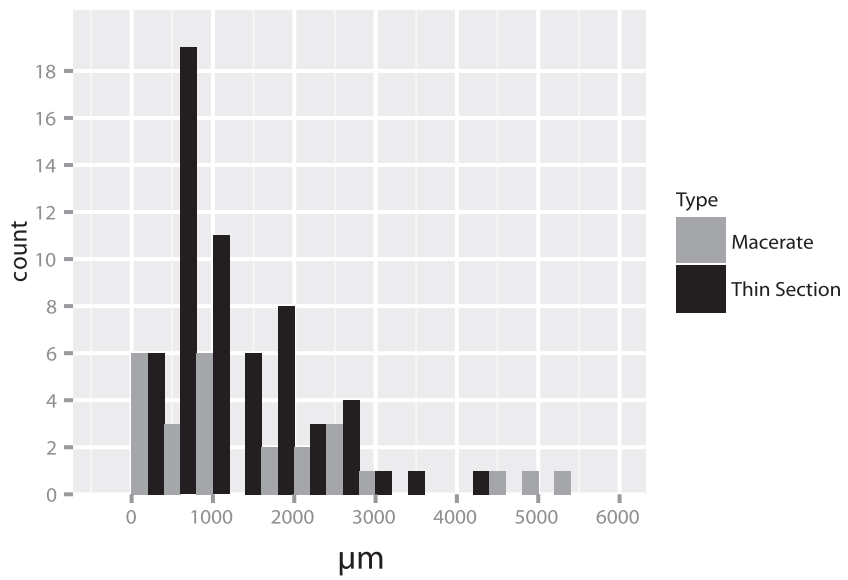

\section{Material in Thin Section}

In thin section, MOWS appear as dark, organic-rich sheets, scattered or imbricated within a matrix of microsparitic to sparitic calcite (Fig. 7). Pieces occur at various low angles with respect to bedding, indicating that the sheets were cohesive enough to behave as clasts as they experienced transport before burial. Fragments measured in thin section range from 0.24 to $4.32 \mathrm{~mm}$ in length (Table 1, Fig. 3A) and 60 to $700 \mu \mathrm{m}$ in thickness (Table 1). Thus, the length of fragments in thin section is similar to that of fragments measured from macerate (Fig. 3A).

The wartlike structures that are present in macerated material can also be recognized in thin section, though their detailed structure is harder to discern (Fig. 7B, C). Where wartlike structures are well preserved in thin section, their interiors are filled with clear calcite crystals, suggesting an originally empty space that was infilled during early diagenesis (Fig. 7C). $\mathrm{W}$ or $\mathrm{S}$ surfaces are not easily distinguishable in thin section material, but surfaces that show possible warty structures in thin section do not appear to exhibit consistent orientation with respect to bedding, consistent with the transport and redeposition of sheetlike structures.

\section{Composition and Taphonomy}

Taishir Formation MOWS consist primarily of carbonaceous material, as determined by Raman spectroscopy and energy-dispersive X-ray (EDS) spectroscopy of macerated material (Fig. 8). Some of the polygonal W surfaces also contain silica (Fig. 8B), but $\mathrm{Si}$ is absent from all analyzed depressed apices of warty structures (Fig. 8B) and freshly cut interiors. Therefore, $\mathrm{Si}$ on the surfaces of specimens can be attributed to diagenetic silicification and not to the original presence of silica minerals in MOWS.

As organic sheets of uncertain composition, MOWS would be subject to taphonomic forces during burial and lithification. The ridges on the $\mathrm{W}$ surfaces and the polygons on the $\mathrm{W}$ surfaces and the interiors of the MOWS material may be interpreted either as original organic features or as diagenetic ones. In particular, the small polygons (Fig. 5) may be casts of calcium carbonate crystals that precipitated during extensive decay and compaction of organic matter and were dissolved by maceration (e.g., Défarge et al. 1994; Kaźmierczak et al. 1996; Tribovillard et al. 2000). Even though the small polygons themselves may be diagenetic, their spatial distribution within specimens is consistent with an initially variable composition of a robust organic structure. This variability would lead to diagenetic alteration only in certain areas, producing

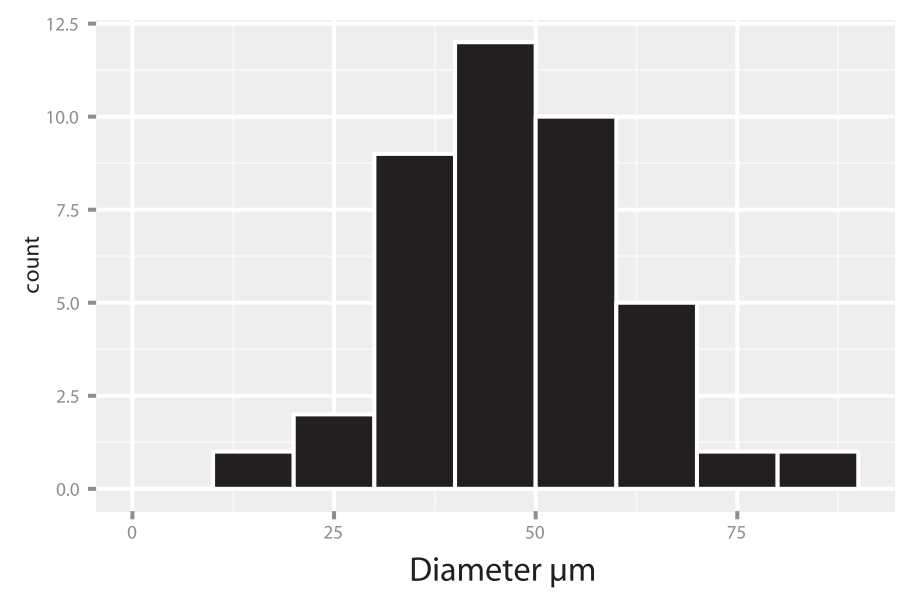

FIG. 3.-Measurements of macerated and thin section material. A) Histogram of length of fossil material in thin section $(\mathrm{N}=60)$ and macerate $(\mathrm{N}=26)$. B) Histogram of the diameter of the depressed wart tops from macerated material $(\mathrm{N}=41)$. 
TABLE 1.-Measurements of MOWS material in thin section and macerates.

\begin{tabular}{|c|c|c|c|c|c|c|c|c|c|c|}
\hline & \multicolumn{5}{|c|}{ Thin section } & \multicolumn{5}{|c|}{ Macerate } \\
\hline & Max & Min & Mean & Standard deviation & $\mathrm{N}$ & $\operatorname{Max}$ & Min & Mean & Standard deviation & $\mathrm{N}$ \\
\hline Wart height & & & & & & $232 \mu \mathrm{m}$ & $166 \mu \mathrm{m}$ & $196 \mu \mathrm{m}$ & 31.9 & 8 \\
\hline Wart base diameter & & & & & & $250 \mu \mathrm{m}$ & $61 \mu \mathrm{m}$ & $119 \mu \mathrm{m}$ & 14.2 & 42 \\
\hline Inner depression diameter & & & & & & $80 \mu \mathrm{m}$ & $17 \mu \mathrm{m}$ & $46.4 \mu \mathrm{m}$ & 41.8 & 41 \\
\hline Fossil longest dimension & $4.32 \mathrm{~mm}$ & $0.24 \mathrm{~mm}$ & $1.2 \mathrm{~mm}$ & 0.84 & 60 & $5.4 \mathrm{~mm}$ & $0.9 \mathrm{~mm}$ & $2.8 \mathrm{~mm}$ & 1.4 & 13 \\
\hline Fossil thickness & $700 \mu \mathrm{m}$ & $60 \mu \mathrm{m}$ & $185 \mu \mathrm{m}$ & 116 & 60 & $342 \mu \mathrm{m}$ & $50.8 \mu \mathrm{m}$ & $158 \mu \mathrm{m}$ & 81.2 & 14 \\
\hline Fossil area & & & & & & $16.0 \mathrm{~mm}^{2}$ & $0.2 \mathrm{~mm}^{2}$ & $3.6 \mathrm{~mm}^{2}$ & 4.1 & 13 \\
\hline
\end{tabular}

polygons only on $\mathrm{W}$ surfaces and in some internal spaces and preserving the denser and smoother organic material on S surfaces and the tops of warty protuberances. The fact that the ridges always skirt warty structures, appear uncompacted, and have the same consistency and texture as the rest of the $\mathrm{W}$ surfaces indicates that these structures are likely primary, and not compressed or folded material.

Studies of Proterozoic microfossils frequently discuss the precipitation of framboidal pyrite in biofilms as a diagenetic mechanism (e.g., Knoll et al. 1981; Vidal and Nystuen 1990), that might result in the formation of organic-walled polygons. Pyrite framboids commonly precipitate within
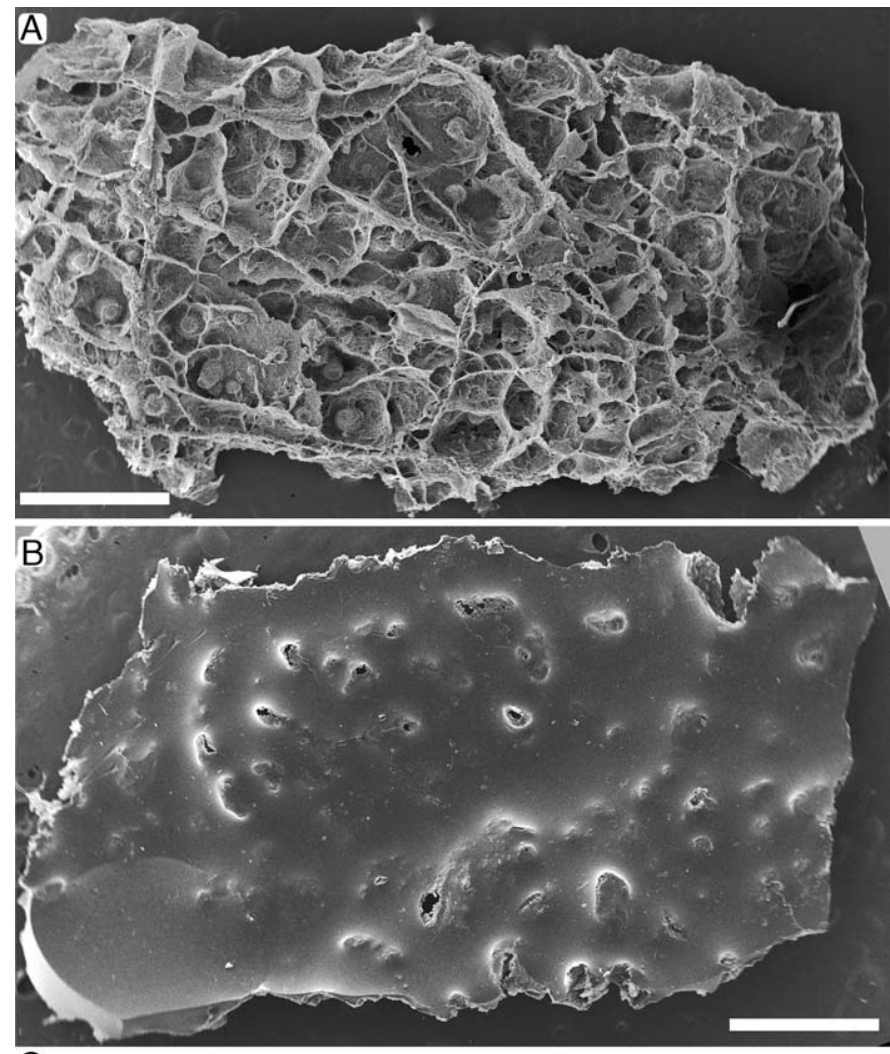

C

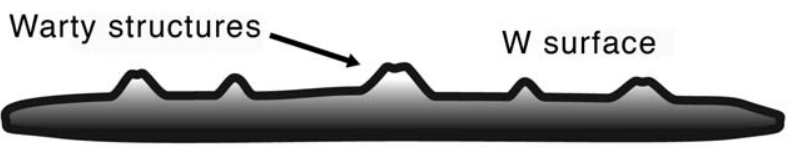

S surface

FIG. 4.-Scanning electron microscope images of MOWS material and schematic drawing showing W and S surfaces. A) MOWS specimen F864-30-A showing ridges and warts on $\mathrm{W}$ surface; scale bar is $1 \mathrm{~mm}$. B) S surface of specimen F864-30-A showing a smooth surface punctuated by perforations; scale bar is $1 \mathrm{~mm}$. C) Schematic drawing showing definition of W and S surfaces of MOWS. microbial biofilms as $\sim 10 \mu \mathrm{m}$ spheroids composed of submicron-sized pyrite grains (e.g., Maclean et al. 2008), but pyrite and sulfur were undetected in the MOWS material in residue and thin section, other fossils from the same samples (Bosak et al. 2011b), bulk residues, and thin sections. Although the absence of sulfur and pyrite from all fossiliferous samples in the Taishir Formation does not rule out the former presence of pyrite, it is unclear why the complete oxidation and removal of pyrite would allow the often remarkable preservation of organic features associated with the MOWS (e.g., Fig. 6). Therefore, the precipitation of pyrite and its subsequent oxidation and complete removal are not likely causes of the organic-walled polygonal structures in MOWS.

\section{BIOLOGICAL ORIGIN AND AFFINITY WITH MODERN GROUPS}

The organic composition, the textural differences between $\mathrm{W}$ and $\mathrm{S}$ surfaces, and the presence of warty protuberances and ridges only on $\mathrm{W}$ surfaces indicate that the MOWS are fossils of originally thin, sheetlike cellular aggregates with morphologically and compositionally distinct areas. While it is notoriously challenging to assign definitive taxonomic affinities to enigmatic fossil material from the Proterozoic (e.g., Maloof et al. 2010; Brain et al. 2012), and it is possible that MOWS represent an extinct and/or unknown clade of organisms, MOWS preserve sufficient morphological features to enable a discussion of taxonomic affinity and comparisons with various modern clades that form sheetlike structures with warty protuberances.

\section{Similarities and Differences Between MOWS and Modern Microbial Biofilms}

Comparisons with Features Found in Bacterial Biofilms.-The unique morphology of warts on the surface of the MOWS material is the key feature which guides the search for modern analogues of MOWS. The presence of cellular material inside the warts, as well as their darkened, concave tops negate any interpretation of these structures as gas bubbles produced by microbial mats (e.g., Bosak et al. 2009, 2010). In addition, MOWS consist of discrete structures that are not internally laminated, a characteristic typical of disrupted or eroded microbial mats (Riding 2000).

However, biofilms made by modern heterotrophic bacteria that form developmentally regulated aggregates with surface protuberances on underlying, sheetlike biofilms do share some morphological features with MOWS. For example, Myxobacteria, Bacillus sp. and Actinomyces can produce sheetlike aggregates with reproductive structures that are attached to elongated stalks called fruiting bodies (McNeil and Skerman 1972; Grilione and Pangborn 1975; lizuka et al. 1998; Webb et al. 2003). The fruiting bodies disperse spores and can have stages that resemble the conical form of the MOWS warts (e.g., Grilione and Pangborn 1975). Despite superficial similarities, the fruiting bodies grow into structures with a narrow stalk topped by a bulbous protuberance that is unlike any structures seen on the surface of MOWS (McNeil and Skerman 1972; Grilione and Pangborn 1975; Webb et al. 2003). All fruiting bodies also form through the production of proteinaceous and polysaccharide matrices that create protuberances with different textures than the surrounding 

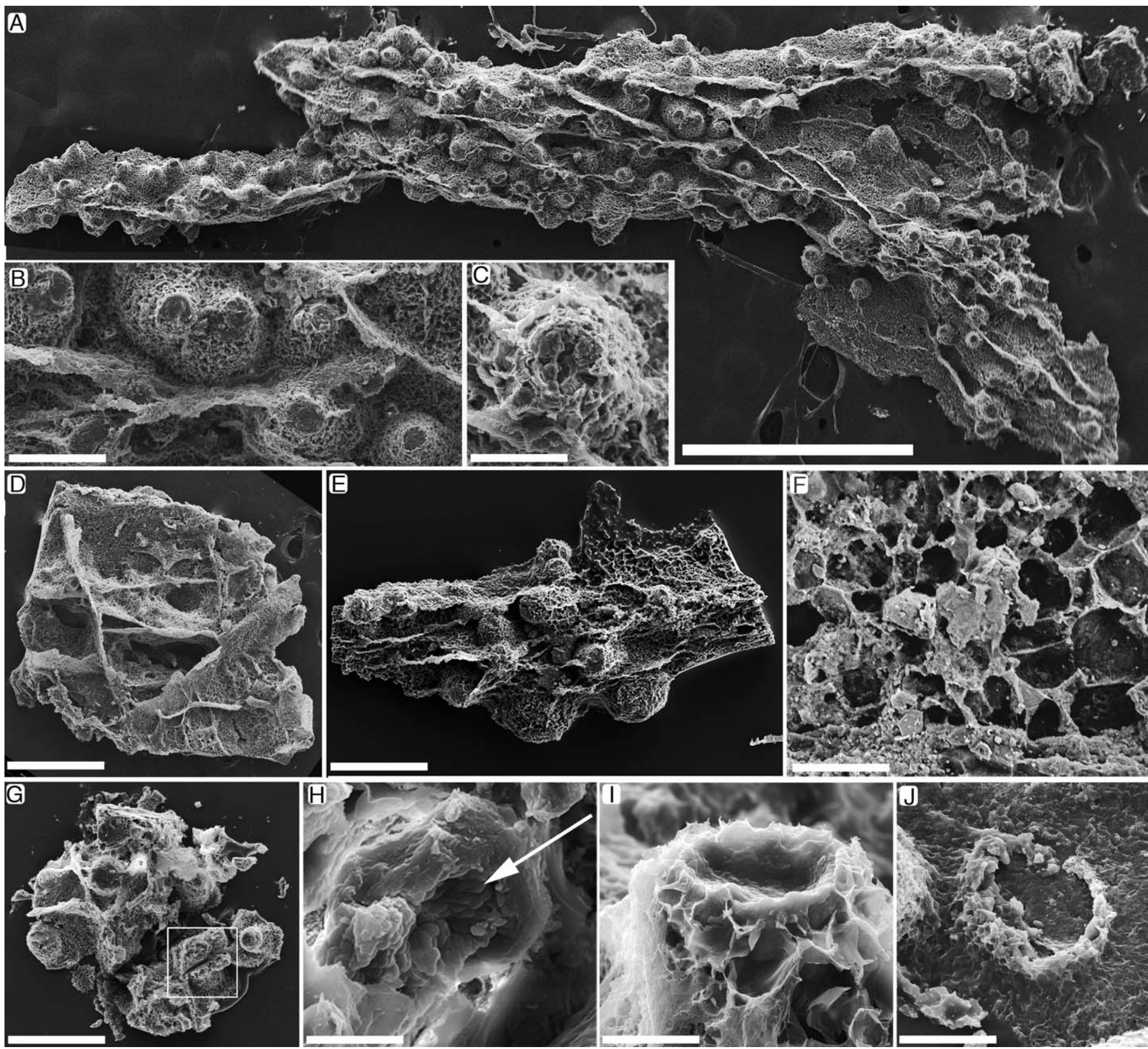

FIG. 5.-Scanning electron microscope images of MOWS material. A) MOWS specimen F864-20-A showing typical morphology of W surface with warts and ridges; scale bar is $1 \mathrm{~mm}$. B) Detail of F864-20-A showing ridges and warts; scale bar is $150 \mu \mathrm{m}$. C) Detail of F864-20-A showing a wart with leathery convex apex; scale bar is $100 \mu \mathrm{m}$. D) MOWS specimen F864-30-B, showing ridges and small warts; scale bar is $800 \mu \mathrm{m}$. E) MOWS specimen F704-128-A showing warts and ridges; scale bar is $200 \mu \mathrm{m}$. F) Detail of polygonal structures on W surface; scale bar is $20 \mu \mathrm{m}$. G) MOWS specimen F864-30-C that was cut with a blade to reveal the internal structure of a wart; white box indicates cut wart seen in view $\mathrm{H}$; scale bar is $500 \mu \mathrm{m}$. H) Close-up of ovular cavity seen in view G; arrow points to cellular structures within the cavity; scale bar is $30 \mu \mathrm{m}$. I) Wart from specimen F864-30-C showing a depressed top and the abrupt transition from polygonal texture to smooth texture of the wart top; scale bar is $30 \mu \mathrm{m}$. J) Circular structure on the W surface of specimen F864-30-D that is consistent with a damaged or detached warty structure; scale bar is $100 \mu \mathrm{m}$.

sheetlike substrate. This is in contrast to the fossil material, which contains polygonal textures on the sides of protuberances, in the flat-lying areas of the fossil sheets, and on ridges, suggesting similar original compositions of these areas. Bacterial fruiting bodies and aerial structures also lack cavities. In addition, the notable lack of reports of bacterial fruiting bodies in natural marine environments calls into question bacterial fruiting bodies as sources of the abundant fossil material in Taishir carbonates.

Comparisons with Aggregates of Heterotrophic Microeukaryotes.-A number of modern microscopic eukaryotes, including those from the
Amoebozoa, Alveolata, Excavata, Stramenopiles, and Opisthokonta, form multicellular aggregates with surface protuberances that bear some morphological similarity to the MOWS fossils. These multicellular social aggregates are commonly known as slime molds (Brown et al. 2012) and can occur as sheets with fruiting bodies that rise up from the surface on a stalk (Worley et al. 1979; Deasey 1982; Brown et al. 2012). The reported morphologies of eukaryotic fruiting bodies are morphologically similar to those of bacterial fruiting bodies and distinct from the MOWS warts: the stalks made by modern microeukaryotes are narrowest at the top where they connect with the fruiting body (sporocarp); the fruiting body is itself is 

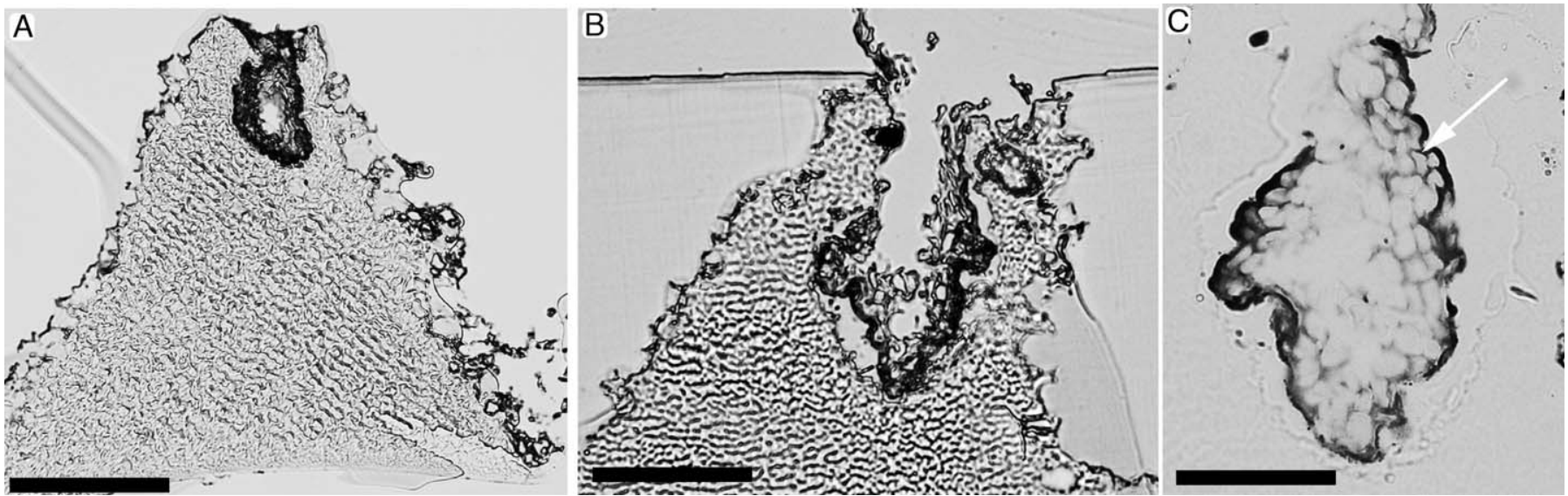

FIG. 6.- Images of embedded and sectioned macerated MOWS warty structures from F864-30; rough texture is an artifact of cutting. A) Section through MOWS material showing a warty structure with an ovular cavity and darkened top. Note irregular edges, which are cross sections through polygonal surface structures; scale bar is $65 \mu \mathrm{m}$. B) Close-up of an ovular cavity showing that it is open to the outside, and is lined with darkened organic material; scale bar is $35 \mu \mathrm{m}$. C) Same sample as in B, with immersion oil in direct contact with the sample. White arrow points to clear outlines of cellular structures; scale bar is $20 \mu \mathrm{m}$.

wider than the stalk and often round or bulbous (Worley et al. 1979; Deasey 1982; Brown et al. 2012), creating protuberances with an irregular profile. When fruiting bodies contain cavities, they lack depressed tops (Worley et al. 1979) and the entire fruiting body has a different texture than the horizontal surfaces. As in the case of bacterial groups that form fruiting bodies, eukaryotic slime molds are mainly terrestrial organisms and thus are not expected to be preserved in a marine setting (Margulis 1990).

Similar arguments apply to groups of marine fungi that form sheetlike structures with fruiting bodies: these organisms degrade organic substrates such as wood or macroalgae and form fruiting bodies that are morphologically distinct from the MOWS (Rohrmann and Molitoris 1986; Shearer et al. 2006). Notably, some groups of terrestrial ascomycete fungi form crustose morphologies with raised fruiting bodies called perithecium that bear rough morphological resemblance to the MOWS, but again, these structures differ morphologically and structurally from the MOWS, do not have depressed tops, and are not reported in marine environments (Jens 2012).

\section{Similarities with Modern and Fossil Algal Groups}

In the absence of adequate modern bacterial and microeukaryotic analogues, better examples of macroscopic, sheetlike forms with distinct wartlike protuberances on a single surface can be found within modern algal groups. Specifically, groups within the Rhodophyta (the red algae), share many characters with MOWS, including aspects of ultrastructure, external morphology, and the morphology and size of wartlike features.

Three main algal groups contain macroscopic taxa-the Rhodophyta, the Phaeophyceae (brown algae), and the Chlorophyta, which contain most marine green algae (Graham and Wilcox 2000). The Phaeophyceae is a poor potential match because the fossil record and molecular clock analyses place their origins solidly within the Mesozoic (Silberfeld et al. 2010). Even if one allows for error in molecular clock estimates, it is highly unlikely that these errors would allow for Cryogenian brown algae (i.e., a >400-million-year discrepancy).

Multicellular green algae likely existed during the Cryogenian (Butterfield et al. 1994), and some clades do exhibit organic unmineralized blade-shaped or sheetlike morphologies (e.g., Ulva). A survey of major Chlorophyta groups from the literature revealed no documented green algae that contain the distinct morphologies, such as warty protuberances on a single surface, that would link them to the MOWS, thus we consider a Chlorophyte affinity unlikely. However, MOWS exhibit a number of morphological similarities with various members of the multicellular marine Rhodophyta, and both fossil and molecular clock data indicate that the Rhodophyte clade had evolved by the Cryogenian (Butterfield 2000; Parfrey et al. 2011). Here, we will consider similarities to two major groups, the Order Gigartinales and the Order Corallinales. We offer these comparisons as a guide, but not as a comprehensive list of all possible affinities within the Rhodophyta.

Similarities to the Rhodophyta Order Gigartinales.-Within the Gigartinales, the Family Gigartinaceae bears the most commonalities with the Taishir material (Fig. 9D-F). These algae have broad, thin, unmineralized thalli, and in many taxa, such as the genera Chondracanthus and Mastocarpus, one surface is covered in bumpy outgrowths (papillae), which contain the reproductive structures (Avila et al. 1999; Hughey and Hommersand 2008; Orostica et al. 2012), while the other surface is smooth and generally featureless (Fig. 9D). The size distribution of papillae also encompasses the range of sizes seen in the MOWS warts (e.g., Hughey and Hommersand 2008).

The papillae themselves share morphological and ultrastructural features with the warty structures on the MOWS. Papillae rise from the surface of the algal sheet and in many stages of development, the base is typically wider than the tip, as in the MOWS warts (Avila et al. 1999; Orostica et al. 2012). Reproductive papillae also contain internal cavities similar to those seen in MOWS. For example, cystocarpic papillae of the Gigartinaceae (female reproductive structures that contain fertilized cells) bear strong resemblance to the MOWS warts: both contain roughly circular internal cavities; a similarity that is enhanced by the presence of celllike structures in the internal cavities of some MOWS warts (Hommersand et al. 1992; Fig. 6C). In addition, the circular ring seen in Figure $5 \mathrm{~J}$ is analogous to papillae scars in modern groups, i.e., the remains of nonactive reproductive structures (Orostica et al. 2012).

None of the known members of the modern group display the distinct ridges seen in the MOWS fossils, but if the polygonal texture seen on the surface and interior of the MOWS specimens is primary, it is similar to ultrastructural features of the Gigartinaceae such as Chondracanthus, which have pseudoparenchymatous polygonal cell walls (Schmidt et al. 2011). Other red algal groups similarly show polygonal cell wall structures (León-Cisneros et al. 2000). Most groups within the Gigartinaceae are frondose and some taxa within the Gigartinaceae, including Mastocarpus papillatus, have a crustose life stage (Fig. 9F); the thin, sheetlike morphology of the MOWS fossils could represent either life habit. 

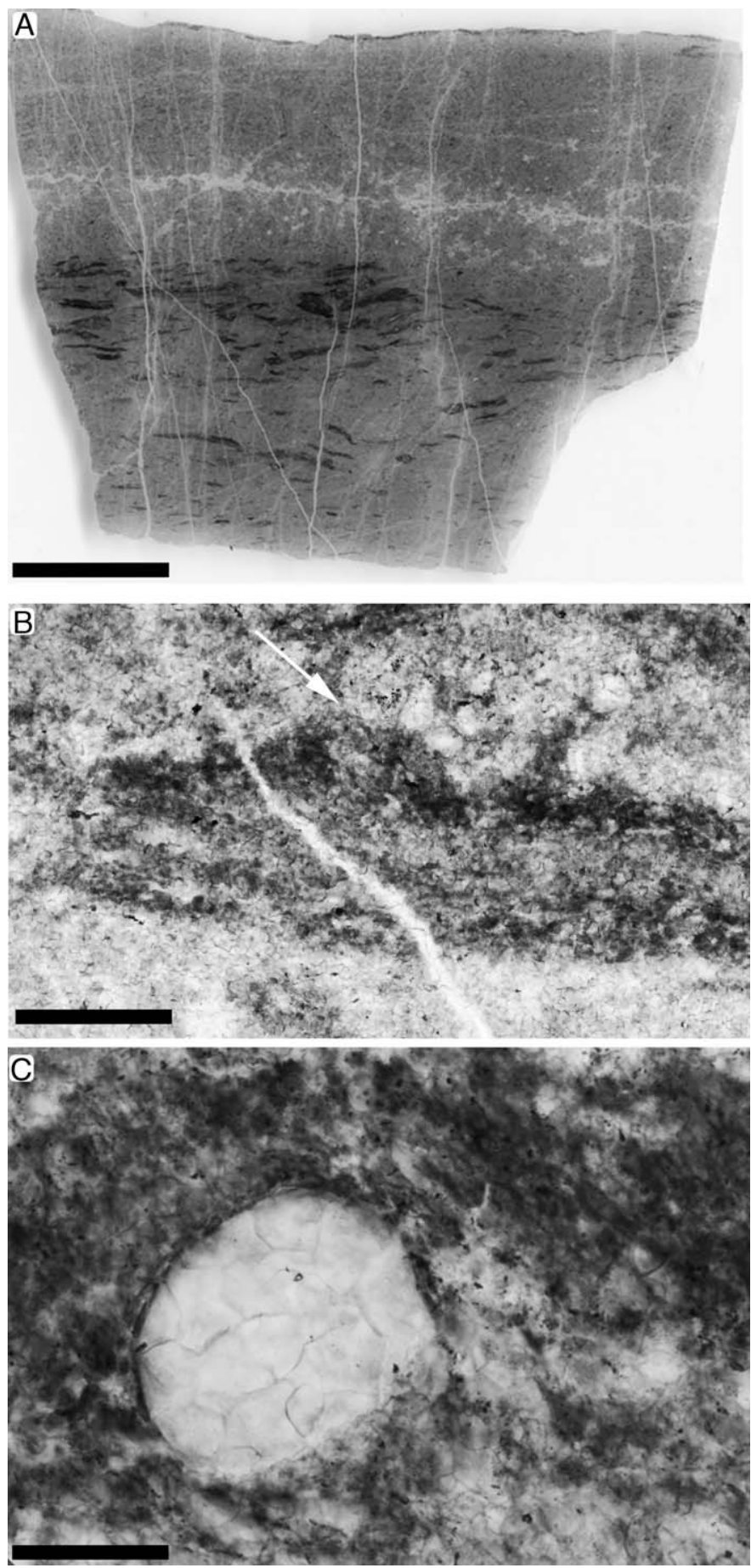

FIG. 7.-A) Photograph of thin section from sample F704-128 taken with incident light and oriented perpendicular to bedding; scale bar is $4 \mathrm{~mm}$. B) Light photomicrograph detail of fossil material from F704-128, arrow pointing to warty protuberance; scale bar is $100 \mu \mathrm{m}$. C) Light photomicrograph detail of fossil material from F704-128 showing calcite-filled wart; scale bar is $40 \mu \mathrm{m}$.

Similarities to the Rhodophyte Order Corallinales.-Another Rhodophyta group containing potential modern analogues to the MOWS are the Order Corallinales, or coralline red algae, a diverse biomineralizing group composed of pseudoparenchymatous cells containing $\mathrm{CaCO}_{3}$ (Graham and Wilcox 2000). During the life cycle of many coralline red algae, raised warty reproductive structures called conceptacles emerge on one surface of the algal thallus (Johansen 1981; Fig. 9A-C). In many taxa, conceptacles are of a similar size and shape to the warty protuberances seen in MOWS, though MOWS warts are generally smaller than coralline conceptacles (Adey et al. 1982; Chamberlain 1992). Coralline conceptacles have open tops; the warty structures of the MOWS also display open tops (Figs. 7, 9C), and the tops of modern conceptacles are compositionally and texturally distinct from the rest of the structure, as in the MOWS (Johansen 1981; Adey et al. 1982; Chamberlain 1992). In addition, the appearance of and the possible remnants of cellular material in the internal wart cavities MOWS are similar, though not identical, to those seen in cross-sectional images of conceptacles (Ringeltaube and Harvey 2000; Fig. 9C).

The average cell size in corallines ranges from $10-40 \mu \mathrm{m}$, consistent with the range of sizes of polygonal cells seen in MOWS (Braga and Aguirre 1995), although a diagenetic origin of the MOWS polygonal structures cannot be rejected. The morphology of corallines is inherently plastic, and modern forms display a high level of ecophenotypy, often changing shape and structure according to substrate differences (Braga and Aguirre 1995). However, thin crustose or foliose morphologies with one warty or bumpy surface and one smoother surface are common and abundant in modern groups, though just as with the Gigartinales, none display the distinct ridges seen in MOWS (Johansen 1981; Steneck 1986). Importantly, unlike the modern corallines, MOWS lack evidence of biomineralization.

Comparison to Previously Described Fossil Rhodophyta.-The fossil record of red algae goes back to at least $1000 \mathrm{Ma}$, with the identification of Bangiomorpha as a member of the Rhodophyte group Bangiales (Butterfield 2000). The next identifiable red algal fossils are ca. $600 \mathrm{Ma}$ and tentatively assigned to the other main group of Rhodophytes, the Florideophyceae (Zhang et al. 1998; Xiao et al. 2004). Both the macroscopic size and the sheetlike form with distinct surfaces found in the MOWS are fundamentally different than the morphologies of both bracketing fossil groups of red algae.

Modern coralline algae are heavily calcified, but there is no evidence for calcification in MOWS specimens. However, a recent reinterpretation of the Silurian fossil Nematothallopsis gotlandii (Smith and Butterfield 2013) as an unmineralized stem group coralline alga suggests that early members of total group corallines were not necessarily biomineralized and that Rhodophyta with polygonal pseudoparenchymatous surface patterns and conceptacle-like structures were present in the Paleozoic.

Reports of organic preservation of red algae beyond Nematothallopsis are rare, so comparisons between MOWS and the nonmineralized members of the Rhodophyta are challenging. Within the fossil record of mineralized coralline algae, comparisons can be made to taxa such as Lithophyllum incrustans (Woelkerling 1983; Kundal 2011) which contain calcite-filled conceptacles in petrographic thin section, similar to structures seen in MOWS (Fig. 7B, C). Other mineralized coralline material such as Neogoniolithon shows similar overall morphological and preservational patterns to the MOWS material in petrographic thin section (Bassi and Nebelsick 2000), although fossils with high similarity to the MOWS have not been reported.

The Taishir MOWS fossils preserve multiple morphological characters that are distinct from structures made by modern bacteria and microeukaryotes, but are similar to the features present in some modern and fossil red algae. Most notable are the wartlike protuberances, which bear similarity to reproductive structures found in a number of red algal groups, but are distinct from protuberances found in bacterial and microeukaryotic clades. Whereas no perfect analogue exists in either the modern or the fossil record, our analysis of the currently available fossil 
A

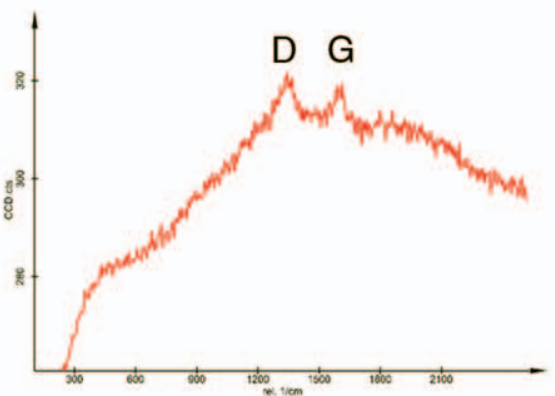

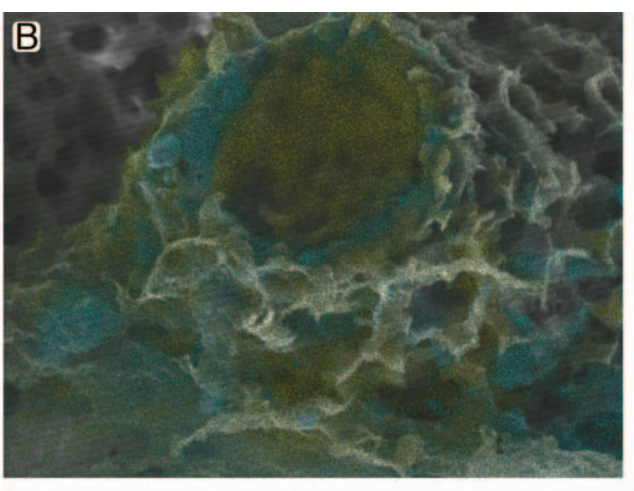

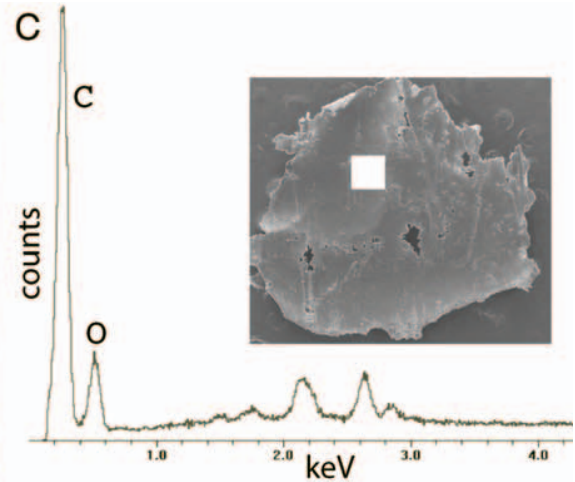

FIG. 8-Chemical composition of MOWS material. A) Raman spectrum of sample from F864-30; D and G bands of organic carbon labeled. B) Electron-dispersive X-ray spectroscopic point map of a wart with a central depressed area from sample F864-20; yellow = carbon, blue-green = silica. C) EDS spectrum showing carbon- and oxygen-dominated signal from smooth S surface of sample from F864-20.

material suggests to us that MOWS are multicellular marine algae, most likely aligned with the Rhodophyta.

\section{IMPLICATIONS FOR MOWS IN INTERGLACIAL SEDIMENTS}

If MOWS represent early Rhodophytes, their discovery in sedimentary rocks from the Cryogenian nonglacial interlude is consistent with the evolutionary trajectory of the Rhodophyta, the oldest identifiable crown group eukaryotes in the rock record, with a fossil record reaching back into the earliest Neoproterozoic (Butterfield 2000). This finding is supported by recent molecular clock analyses, which place the roots of red algal clade deep in the Neoproterozoic or even Mesoproterozoic (Parfrey et al. 2011) and indicate a subsequent diversification of red algae into at least two major clades: Bangiales and Florideophyceae. Our tentative assignment of the MOWS fossils to the Rhodophyta would bridge a gap in the fossil record of the red algae, between the ca. $1000 \mathrm{Ma}$ Bangiomorpha (Butterfield 2000), and ca. $600 \mathrm{Ma}$ fossils tentatively assigned to the Florideophycea (Zhang et al. 1998; Xiao et al. 2004).
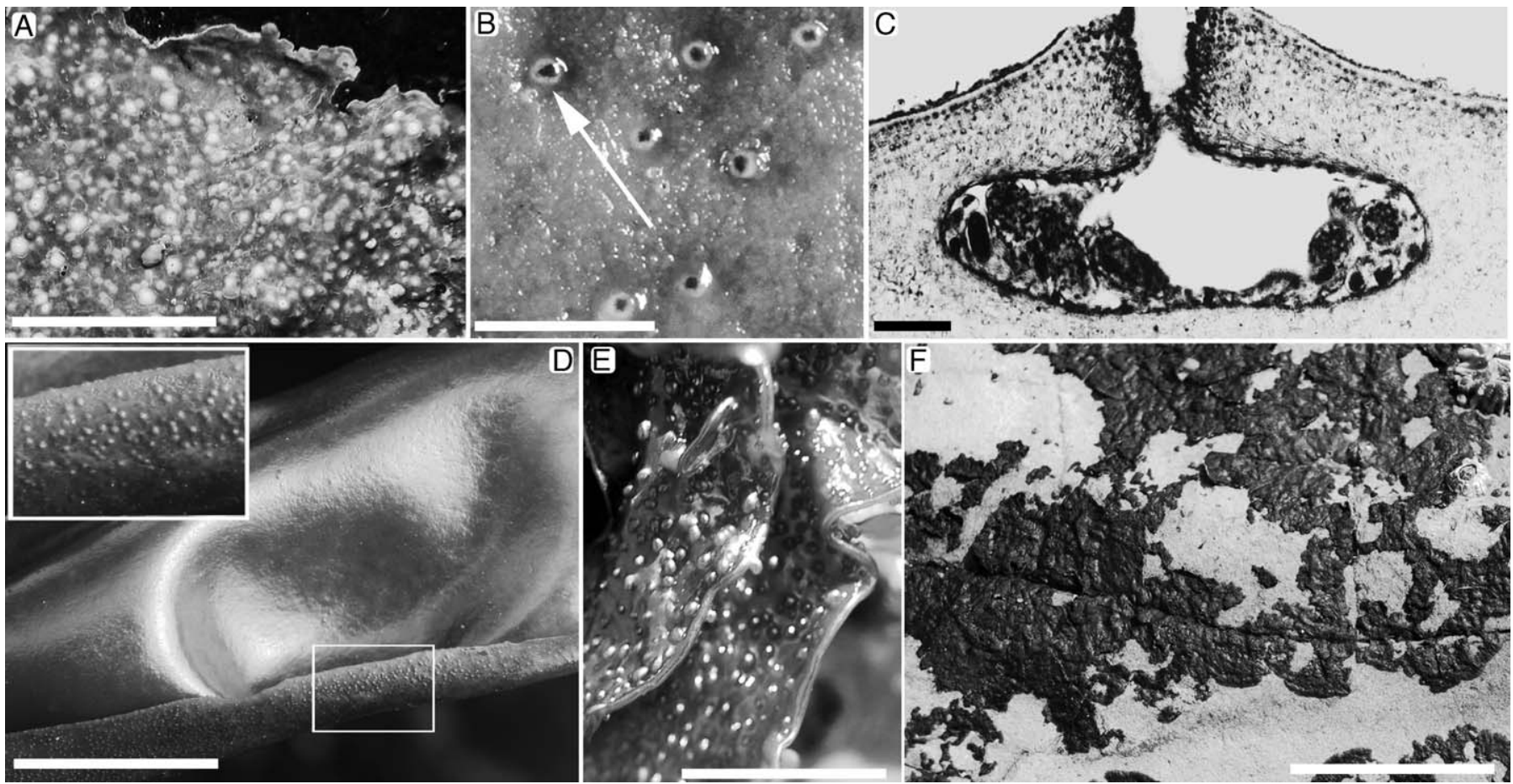

FIG. 9.-Examples of modern red algal groups. A) Modern crustose coralline alga showing warty structures; scale bar is $1 \mathrm{~cm}$. Used with permission from Smithsonian Institution, National Museum of Natural History, Department of Botany. B) Modern crustose coralline alga Lithophyllum incrustans, arrows showing conceptacles with darker open pores; scale bar is $5 \mathrm{~mm}$. Copyright Malcolm Storey (creative commons license). C) Cross-section through a uniporate conceptacle from the modern coralline algae Neogoniolithon brassica-florida; scale bar is $100 \mu \mathrm{m}$. Modified from Ringeltaube and Harvey (2000). D) Mazzaella flaccida, a modern frondose member of the Gigartinaceae. Note that one surface is smooth while the other is bumpy; scale bar is $3 \mathrm{~cm}$. White box in main image shown in detail in upper left showing papillae on the bumpy surface. Copyright Scott Loarie (creative commons license). E) Mastocarpus papillatus, a modern member of the Gigartinaceae; bumps on surface are reproductive papillae; scale bar is $2 \mathrm{~cm}$. Copyright kqedquest (creative commons license). F) A modern encrusting form of Mastocarpus papillatus; scale bar is 4 cm. Copyright kqedquest (creative commons license). 
MOWS, as remnants of multicellular and macroscopic organisms, also paint an unexpected ecological picture of Cryogenian carbonatedepositing environments. Broadly, the Neoproterozoic fossil record tells a story of ecological evolution from a biosphere dominated by microbial communities (Bosak et al. 2013) to a world of larger organisms and increasingly complex ecosystems, but it has been unclear whether the Cryogenian record is one of transition or stasis (e.g., Knoll et al. 2006). Biotic transitions during this time may be related to a putative rise in atmospheric oxygen concentrations that would have had consequences for other biogeochemical cycles. For example, a rise of oxygen may have reduced persistent nitrogen limitation for eukaryotic groups, including algae (Knoll et al. 2006; Glass et al. 2009). Studies of modern marine environments have shown that, given abundant access to nitrate, algae will outcompete cyanobacterial mats (Fong and Zedler 1993). Thus, higher bioavailable nitrogen levels in Cryogenian coastal seawater may have enabled the local and episodic proliferation of algae in shallowwater environments. However, it is important to note that multicellular algae do not become common in marine environments until at least the Ediacaran (Knoll et al. 2006; Xiao and Dong 2006). Therefore, if the MOWS represent marine macroalgae, their sporadic occurrence in Cryogenian carbonates suggests that the radiation of various algal groups may have been kept in check until the late Ediacaran.

\section{CONCLUSIONS}

MOWS are the remains of multicellular, developmentally complex organisms that coexisted with the planktonic eukaryotes (Bosak et al. 2011b). Older multicellular eukaryotic fossils exist (Butterfield 2000, 2004, 2009), but fossils that resemble MOWS in scale and/or morphology have not been reported in older or coeval strata. The discovery of MOWS in the Taishir Formation adds a new element to a growing record of eukaryotic fossil diversity and multicellularity between the Sturtian and Marinoan glaciations, and distinguishes the Taishir assemblages from pre-Sturtian Neoproterozoic fossil biota, which are dominated by microscopic eukaryotes (e.g., Vidal and Ford 1985; Knoll et al. 2006).

MOWS fossils share numerous characters with various groups of red algae, and the same characters are absent from other modern multicellular structures formed by either heterotrophic eukaryotes or bacteria. The tentative assignment of MOWS to the red algae may indicate that the Rhodophyta clade continued to diversify and explore new niches during the Cryogenian nonglacial interlude, perhaps as a result of permissive environmental conditions. Regardless of the specific taxonomic assignment of MOWS, the uniqueness of these fossils indicates that continued sampling and analyses of Cryogenian strata, including carbonate lithologies, will lead to an increase in the known diversity of Neoproterozoic fossils and expand our understanding of when and how early representatives of modern eukaryotes evolved in marine ecosystems.

\section{ACKNOWLEDGMENTS}

This work was funded through a NASA Astrobiology Institute grant to Massachusetts Institute of Technology, a NASA Exobiology Grant to TB and FAM, and Williams College. Nicki Watson and Nancy Piatzyc aided in electron microscopy preparation and imaging assistance. Raman microspectroscopy and some SEM imaging were carried out at the Harvard University Center for Nanoscale Systems. Boston Public Schools science teacher Adriana Costache first noted MOWS during a summer internship at MIT. We thank Uyanga Bold for help with initial field work. R. Kodner, S. Golubic, and two anonymous reviewers provided helpful feedback on earlier drafts.

\section{REFERENCES}

Adey, W.H., Townsend, R.A., And Boykins, W.T., 1982, The crustose coralline algae (Rhodophyta: Corallinaceae) of the Hawaiian Islands: Smithsonian Contributions to the Marine Sciences, 74 p.
Avila, M., Candia, A., Nuñez, M., and Romo, H., 1999, Reproductive biology of Gigartina skottsbergii (Gigartinaceae, Rhodophyta) from Chile: Hydrobiologia, v. 398 , p. $149-157$.

Bassi, D., AND Nebelsick, J.H., 2000, Calcareous algae from the lower Oligocene Gornji Grad Beds of northern Slovenia: Rivista Italiana di Paleontologia e Stratigrafia, v. 106 , p. $99-122$

Bold, U., Macdonald, F A., Smith, E.F., Crowly, J.C., and Minjin, Ch., 2013, Elevating the Neoproterozoic Tsagaan-Olom Formation to a Group. Mongolian Geoscientist, 39, 89-94.

Bosak, T., Liang, B., Sim, M.S., and Petroff, A.P., 2009, Morphological record of oxygenic photosynthesis in conical stromatolites: Proceedings of the National Academy of Sciences of the United States of America, v. 106, no. 27, p. 10939-10943. Bosak, T., Bush, J.W.M., Flynn, M.R., Liang, B., Ono, S., Petroff, A.P., And Sim, M.S., 2010, Formation and stability of oxygen-rich bubbles that shape photosynthetic mats: Geobiology, v. 8, no. 1, p. 45-55.

Bosak, T., Lahr, D.J.G., Pruss, S.B., Macdonald, F.A., Dalton, L., and Matys, E., 2011a, Agglutinated tests in post-Sturtian cap carbonates of Namibia and Mongolia: Earth and Planetary Science Letters, v. 308, no. 1-2, p. 29-40.

Bosak, T., Macdonald, F., Lahr, D., and Matys, E., 2011b, Putative Cryogenian ciliates from Mongolia: Geology, v. 39, no. 12, p. 1123-1126.

Bosak, T., Lahr, D.J.G., Pruss, S.B., Macdonald, F.A., Gooday, A.J., Dalton, L., AND Matys, E.D., 2011c, Possible early foraminiferans in post-Sturtian (716-635 Ma) cap carbonates: Geology, v. 40, no. 1, p. 67-70.

Bosak, T., Knoll, A.H., and Petroff, A.P., 2013, The meaning of stromatolites: Annual Review of Earth and Planetary Sciences, v. 41, no. 1, p. 21-44.

Braga, J.C., And Aguirre, J., 1995, Taxonomy of fossil coralline algal species: Neogene Lithophylloideae (Rhodophyta, Corallinaceae) from southern Spain: Review of Palaeobotany and Palynology, v. 86, no. 3, p. 265-285.

Brain, C.K.B., Prave, A.R., Hoffmann, K.-H., Fallick, A.E., Botha, A., Herd, D.A Sturrock, C., Young, I., Condon, D.J., And Allison, S.G., 2012, The first animals: ca. 760-million-year-old sponge-like fossils from Namibia: South African Journal of Science, v. 108 , no. $1 / 2$, doi: $10.4102 /$ sajs.v108i1/2.658.

Brown, M.W., Kolisko, M., Silberman, J.D., And Roger, A.J., 2012, Aggregative multicellularity evolved independently in the eukaryotic supergroup Rhizaria: Current Biology, v. 22, no. 12, p. 1123-1127.

Butterfield, N.J., 2000, Bangiomorpha pubescens n. gen., n. sp.: implications for the evolution of sex, multicellularity, and the Mesoproterozoic/Neoproterozoic radiation of eukaryotes: Paleobiology, v. 26, no. 3, p. 386-404.

Butterfield, N.J., 2004, A vaucheriacean alga from the middle Neoproterozoic of Spitsbergen: implications for the evolution of Proterozoic eukaryotes and the Cambrian explosion: Paleobiology, v. 30, no. 2, p. 231-252.

Butterfield, N.J., 2009, Modes of pre-Ediacaran multicellularity: Precambrian Research, v. 173, p. 201-211.

Butterfield, N.J., Knoll, A.H., And Swett, K., 1994, Paleobiology of the Neoproterozoic Svanbergfjellet Formation, Spitsbergen: Lethaia, v. 27, no. 1, p. $76-76$.

Calver, C., Crowley, J., Wingate, M., Evans, D., Raub, T., and Schmitz, M., 2013, Globally synchronous Marinoan deglaciation indicated by U-Pb geochronology of the Cottons Breccia, Tasmania, Australia: Geology, v. 41, no. 10, p. 1127-1130.

Chamberlain, Y.M., 1992, Observations on two melobesioid crustose coralline red algal species from the British Isles: Exilicrusta parva, a new genus and species, and Lithothamnion sonderi Hauck: British Phycological Journal, v. 27, no. 2, p. 185-201. Dalton, Bosak, T., Macdonald, F.A., Lahr, D.J.G., and Pruss, S.B., 2013, Preservational and morphological variability of assemblages of agglutinated eukaryotes in Cryogenian cap carbonates of Northern Namibia: PALAIOS, v. 28, no. 2 , p. $67-79$

Deasey, M.C., 1982, Spore formation by the cellular slime mold Fonticula alba: Mycologia, v. 74, p. 607-613.

Défarge, C., Trichet, J., Maurin, A., and Hucher, M., 1994, Kopara in Polynesian atolls: early stages of formation of calcareous stromatolites: Sedimentary Geology, v. 89 , no. 1 , p. $9-23$.

FonG, R.M.D., AND Zedler, J.B., 1993, Competition with macroalgae and benthic cyanobacterial mats limits phytoplankton abundance in experimental microcosms: Marine Ecology Progress Series, v. 100, p. 97-102.

Glass, J.B., Wolfe-Simon, F., and Anbar, A.D., 2009, Coevolution of metal availability and nitrogen assimilation in cyanobacteria and algae: Geobiology, v. 7, no. 2 , p. $100-123$

Graham, L.E., And Wilcox, L.W., 2000, Algae: Upper Saddle River, New Jersey, Prentice Hall, 640 p.

Grilione, P.L., And Pangborn, J., 1975, Scanning electron microscopy of fruiting body formation by myxobacteria: Journal of Bacteriology, v. 124, no. 3, p. 1558-1565.

Hofmann, H.J., Narbonne, G.M., and Aitken, J.D., 1990, Ediacaran remains from intertillite beds in northwestern Canada: Geology, v. 18, no. 12, p. 1199-1202.

Hommersand, M., FredericQ, S., and Cabioch, J., 1992, Developmental morphology of Gigartina pistillata (Gigartinaceae, Rhodophyta): Phycologia, v. 31, no. 3-4, p. 300 325 .

Hughey, J.R., And Hommersand, M.H., 2008, Morphological and molecular systematic study of Chondracanthus (Gigartinaceae, Rhodophyta) from Pacific North America: Phycologia, v. 47, no. 2 .

Iizuka, T., Jojima, Y., Fudou, R., And Yamanaka, S., 1998, Isolation of myxobacteria from the marine environment: FEMS Microbiology Letters, v. 169, no. 2, p. 317-322 Jens, P.H., 2012, The Kingdom of Fungi: Princeton, New Jersey, Princeton University Press, $265 \mathrm{p}$ 
Johansen, H.W., 1981, Coralline Algae, a First Synthesis: CRC Press, 239 p.

Johnston, D.T., Macdonald, F.A., Gill, B.C., Hoffman, P.F., and Schrag, D.P., 2013, Uncovering the Neoproterozoic carbon cycle: Nature, v. 483, no. 7389, p. 320323, doi: 10.1038 /nature10854

Każmierczak, J., Coleman, M.L., Gruszczynski, M., and Kempe, S., 1996, Cyanobacterial key to the genesis of micritic and peloidal limestones in ancient seas: Acta Palaeontologica Polonica, v. 41, no. 4, p. 319-338

Knoll, A.H., Blick, N., and AwramiK, S.M., 1981, Stratigraphic and ecologic implications of late Precambrian microfossils from Utah: American Journal of Science, v. 281 , no. 3 , p. $247-263$.

Knoll, A.H., Javaux, E.J., Hewitt, D., and Cohen, P., 2006, Eukaryotic organisms in Proterozoic oceans: Royal Society, Philosophical Transactions, Series B: Biological Sciences, v. 361, no. 1470 , p. 1023-1038.

KUNDAL, P., 2011, Generic distinguishing characteristics and stratigraphic ranges of fossil corallines: an update: Journal of the Geological Society of India, v. 78, no. 6, p. $571-586$.

León-Cisneros, K., Riosmena-Rodríguez, R., And Neto, A.I., 2010, A re-evaluation of Scinaia (Nemaliales, Rhodophyta) in the Azores: Helgoland Marine Research, v. 65, no. 2, p. 111-121.

MacDonald, F.A., 2011, The Tsagaan Oloom Formation, southwestern Mongolia: Geological Society, London, Memoirs, v. 36, no. 1, p. 331-337.

Macdonald, F.A., Jones, D.S., and Schrag, D.P., 2009, Stratigraphic and tectonic implications of a newly discovered glacial diamictite-cap carbonate couplet in southwestern Mongolia: Geology, v. 37, no. 2, p. 123-126.

MacDonald, F.A., and Jones, D.S., 2011, The Khubsugul Group, northern Mongolia: Geological Society, London, Memoirs, v. 36, no. 1, p. 339-345.

Maclean, L.C.W., Tyliszczak, T., Gilbert, P.U.P.A., Zhou, D., Pray, T.J., Onstott, T.C., AND Southam, G., 2008, A high-resolution chemical and structural study of framboidal pyrite formed within a low-temperature bacterial biofilm: Geobiology, v. 6 , no. 5 , p. $471-480$

Maloof, A.C., Rose, C.V., Beach, R., Samuels, B.M., Calmet, C.C., Erwin, D.H., Poirier, G.R., Yao, N., AND Simons, F.J., 2010, Possible animal-body fossils in preMarinoan limestones from South Australia: Nature Publishing Group, v. 3, no. 9, p. $653-659$

MARgulis, L., 1990, Handbook of Protoctista: Jones and Bartlett, 914 p.

McNeil, K.E., and Skerman, V., 1972, Examination of myxobacteria by scanning electron microscopy: International Journal of Systematic Bacteriology, v. 22, no. 4, p. $243-250$.

Orostica, M.H., Otaiza, R.D., and Neill, P., 2012, Blades and papillae as likely dispersing propagulesin Chilean populations of Mastocarpus sp. (Rhodophyta, Gigartinales): Revista de Biologia Marina y Oceanografia, v. 47, no. 1, p. 109-119.

Parfrey, L.W., Lahr, D.J., KNoll, A.H., and Katz, L.A., 2011, Estimating the timing of early eukaryotic diversification with multigene molecular clocks: Proceedings of the National Academy of Sciences of the United States of America, v. 108, no. 33, p. 13624-13629.

RIDING, R., 2000, Microbial carbonates: the geological record of calcified bacterial-algal mats and biofilms: Sedimentology, v. 47, no. sl, p. 179-214.

Ringeltaube, P., and Harvey, A., 2000, Non-geniculate coralline algae (Corallinales, Rhodophyta) on Heron Reef, Great Barrier Reef (Australia): Botanica Marina, v. 43 , no. 5 , p. $431-454$.

Rohrmann, S., And Molitoris, H.-P., 1986, Morphological and physiological adaptations of the cyphellaceous fungus Halocyphina villosa (Aphyllophorales) to its marine habitat: Botanica Marina, v. 29, no. 6, p. 539-548

Rooney, A.D., Macdonald, F.A., Strauss, J.V., Dudás, F.Ö., Hallmann, C., and Selby, D., 2014, Re-Os geochronology and coupled Os-Sr isotope constraints on the Sturtian snowball Earth: Proceedings of the National Academy of Sciences of the United States of America, v. 111, no. 1, p. 51-56.
Schmidt, É.C., Pereira, B., Pontes, C.L.M., Santos, R., Scherner, F., Horta, P.A., Paula Martins, R., Latini, A., Maraschin, M., and Bouzon, Z.L., 2011, Alterations in architecture and metabolism induced by ultraviolet radiation-B in the carragenophyte Chondracanthus teedei (Rhodophyta, Gigartinales): Protoplasma, v. 249, no. 2, p. $353-367$

Shearer, C.A., Descals, E., Kohlmeyer, B., Kohlmeyer, J., Marvanová, L., Padgett, D., Porter, D., Raja, H.A., Schmit, J.P., Thorton, H.A., and Voglymayr, H., 2006, Fungal biodiversity in aquatic habitats: Biodiversity and Conservation, v. 16, no. 1, p. 49-67.

Shields-Zhou, G., Hill, A., and Macgabhann, B., 2012, The Cryogenian Period, in The Geologic Time Scale, p. 393-411.

Silberfeld, T., Leigh, J.W., Verbruggen, H., Cruaud, C., de Reviers, B., and Rousseau, F., 2010, A multi-locus time-calibrated phylogeny of the brown algae (Heterokonta, Ochrophyta, Phaeophyceae): investigating the evolutionary nature of the "brown algal crown radiation": Molecular Phylogenetics and Evolution, v. 56, no. 2 , p. 659-674.

Smith, M.R., AND Butterfield, N.J., 2013, A new view on Nematothallus: coralline red algae from the Silurian of Gotland: Palaeontology, v. 56, no. 2, p. 345-357.

StenecK, R.S., 1986, The ecology of coralline algal crusts: convergent patterns and adaptative strategies: Annual Review of Ecology and Systematics, v. 17, p. 273-303.

Tribovillard, N., Trentesaux, A., Trichet, J., and Défarge, C., 2000, A Jurassic counterpart for modern kopara of the Pacific atolls: lagoonal, organic matter-rich, laminated carbonate of Orbagnoux (Jura Mountains, France): Palaeogeography, Palaeoclimatology, Palaeoecology, v. 156, no. 3, p. 277-288.

VIDAL, G., AND FoRD, T.D., 1985, Microbiotas from the late Proterozoic Chuar Group (northern Arizona) and Uinta Mountain Group (Utah) and their chronostratigraphic implications: Precambrian Research, v. 28, no. 3, p. 349-389.

Vidal, G., AND Nystuen, J.P., 1990, Micropaleontology, depositional environment, and biostratigraphy of the upper Proterozoic Hedmark Group, southern Norway: American Journal of Science, v. 290, p. 170-211.

Webb, J.S., Givskov, M., And KJelleberg, S., 2003, Bacterial biofilms: prokaryotic adventures in multicellularity: Current Opinion in Microbiology, v. 6, no. 6, p. 578 585 .

WoelKerling, W.J., 1983, A taxonomic reassessment of Lithophyllum (Corallinaceae, Rhodophyta) based on studies of R.A. Philippi's original collections: British Phycological Journal, v. 18, p. 299-327.

Worley, A.C., Raper, K.B., AND Hohl, M., 1979, Fonticula alba: a new cellular slime mold (Acrasiomycetes): Mycologia, v. 71, p. 746-760.

XIAO, S., And Dong, L., 2006, On the morphological and ecological history of Proterozoic macroalgae, in Neoproterozoic Geobiology and Paleobiology: Springer Netherlands, p. 57-90

Xiao, S., Knoll, A.H., Yuan, X., and Pueschel, C.M., 2004, Phosphatized multicellular algae in the Neoproterozoic Doushantuo Formation, China, and the early evolution of florideophyte red algae: American Journal of Botany, v. 91, no. 2, p. $214-227$

Zhang, Y., Yin, L., Xiao, S., and Knoll, A.H., 1998, Permineralized fossils from the terminal Proterozoic Doushantuo Formation, south China: Memoir (The Paleontological Society), p. 1-52.

Zhou, C., Tucker, R., Xiao, S., Peng, Z., Yuan, X., and Chen, Z., 2004, New constraints on the ages of Neoproterozoic glaciations in south China: Geology, v. 32, p. $437-440$

Received 4 August 2014; accepted 4 November 2014. 